Sмгтн, R. H. (1951). J. gen. Microbiol. 5, 772-780.

\title{
A Study of the Role of Inositol in the Nutrition of Nematospora gossypii and Saccharomyces carlsbergensis
}

\author{
BY R. H. SMITH \\ Biochemical Laboratories, Department of Botany, \\ Imperial College of Science and Technology, London, S.W.7
}

\begin{abstract}
SUMMARY: A study has been made of the uptake of inositol from liquid media by Nematospora gossypii and Saccharomyces carlsbergensis 4228. All the available inositol was rapidly removed from the medium so long as growth continued. Small amounts were recovered from the organisms by water extraction, and up to $75 \%$ from the yeast by acid hydrolysis. This bound inositol in the yeast possessed properties resembling those of phytin. On media deficient in inositol, cell division was incomplete. No influence of inositol on the respiratory system of $S$. carlsbergensis could be detected. $\gamma$-Hexachlorocyclohexane inhibited growth and respiration of intact yeast cells, but not respiration of dried yeast preparations; its effect was not reversed by inositol. Streptidine, strepturea and streptamine neither inhibited growth nor could replace inositol as a growth factor.
\end{abstract}

Although meso-inositol was the first member of the 'bios' complex to be identified (Eastcott, 1928) its function in metabolism remains uncertain. That it takes part in some enzyme system was postulated by Slade (1945), who suggested that the toxic action of $\gamma$-hexachlorocyclohexane towards some insects is due to antagonism towards meso-inositol, to which it was thought to be structurally analogous. Support for this theory was provided by the work of Kirkwood \& Phillips (1946) who found that inhibition of growth of a strain of yeast by $\gamma$-hexachlorocyclohexane was overcome by $m$-inositol (see also Buston, Jacobs \& Goldstein, 1946). Lane \& Williams (1948) stated that highly purified pancreatic amylase contains an exceptionally high proportion of mesoinositol, and that its activity is decreased by $\gamma$-hexachlorocyclohexane and partially restored by meso-inositol; these observations have, however, been disputed by Fischer \& Bernfeld (1949). The present work was designed to examine more closely the part played by meso-inositol (in the sequel referred to as inositol) in the growth and metabolism of certain micro-organisms.

\section{EXPERIMENTAL}

\section{Organisms and culture methods}

The organism most frequently used was a strain (4228) of Saccharoymces carlsbergensis known to require inositol as a nutrient. Stock cultures were maintained on malt extract agar containing $2 \%(w / v)$ of glucose. For the preparation of standard inocula, a transfer from the stock culture was grown for $24 \mathrm{hr}$. at $30^{\circ}$ in $10 \mathrm{ml}$. of glucose malt extract broth; the cells were centrifuged and resuspended in $0.9 \%$ sterile saline to give a faintly opalescent suspension (c. 230,000 cells $/ \mathrm{ml}$.). In other experiments, Nematospora (Ashbya) gossypii was used, the technique being that of Buston \& Pramanik (1931) 
except that in the medium the lentil extract supplement was replaced by biotin and aneurin (2 $\mu \mathrm{g}$. and $1 \mathrm{mg}$. respectively/100 ml. medium).

\section{Assay of inositol}

Chemical methods for the determination of inositol are laborious and lack sensitivity, and a microbiological assay method was, therefore, sought. It had been suggested by Hopkins \& Pennington (1947) that $S$. carlsbergensis 4228, employed by Atkin, Schultz, Williams, \& Frey (1943) for the assay of pyridoxin, might be suitable for the assay of inositol. This was found to be the case, the method finally adopted being as follows. Five ml. of the basal medium of Hopkins \& Pennington, but omitting inositol, were placed in each of a number of $50 \mathrm{ml}$. conical flasks, the solution containing inositol was added and the volume made up to $9 \mathrm{ml}$. with distilled water. After sterilization (10 lb./sq. in., $10 \mathrm{~min}$.) each flask was inoculated with $1 \mathrm{ml}$. of the standard yeast suspension and incubated at $30^{\circ}$ for $10 \mathrm{hr}$. with constant shaking. The flasks were then placed in the refrigerator for $15 \mathrm{~min}$. and $1 \mathrm{ml}$. of $40 \%$ formaldehyde solution was added to each. The cultures were then centrifuged and the cells resuspended in $10 \mathrm{ml}$. of $0.9 \%$ saline. The amount of growth was estimated turbidimetrically by means of a Spekker absorptiometer. Satisfactory results were obtained when the amount of inositol ranged from 0 to $10 \mu \mathrm{g} . / 10 \mathrm{ml}$. , the latter figure representing the upper limit of accuracy. In some experiments it was found preferable to assess the growth by centrifuging the culture under standard conditions in a calibrated centrifuge tube. This was done because the yeast cells failed to divide normally, but remained in aggregates, thus rendering turbidimetric measurements inaccurate; instances are noted below.

\section{Uptake of inositol by growing organisms}

$N$. gossypii. The organism was grown on $25 \mathrm{ml}$. portions of liquid medium for periods varying from 6 to 17 days at $30^{\circ}$. Inositol was added to the medium in concentrations up to $6 \mu \mathrm{g} . / \mathrm{ml}$. At the end of the growth period mycelium was removed on sintered-glass filters; the filtrates were evaporated and assayed for residual inositol. It was found that after 8 days nearly maximum growth had taken place in the presence of only $0.4 \mu \mathrm{g} . / \mathrm{ml}$. inositol, although when 15 times this amount was available the greater part was still taken up; the dry weight of mycelium only increased by about one-third, however. Table 1 gives some typical results.

Table 1. Removal of inositol from the medium by $\mathrm{N}$. gossypii

\begin{tabular}{|c|c|c|c|c|}
\hline \multicolumn{3}{|c|}{ Time of observation (days) } & \multicolumn{2}{|c|}{ Time of observation (days) } \\
\hline $\mathbf{0}$ & 8 & 17 & 8 & 17 \\
\hline \multicolumn{3}{|c|}{ Inositol in medium ( $\mu \mathrm{g} . / 25 \mathrm{ml})}$. & \multicolumn{2}{|c|}{ Dry wt. of mycelium (mg.) } \\
\hline 10 & 0 & 0 & 27 & 15 \\
\hline 50 & $\mathbf{0}$ & $\mathbf{0}$ & $\mathbf{2 8}$ & 25 \\
\hline 100 & 0 & 0 & 32 & 30 \\
\hline 150 & 17 & 12 & 35 & $\mathbf{2 8}$ \\
\hline
\end{tabular}


S. carlsbergensis 4228. The use of this organism has several practical advantages over $N$. gossypii, and it was preferred for more extensive experiments. In general, $5 \mathrm{ml}$. of basal medium were placed in each of twenty $50 \mathrm{ml}$. conical flasks together with $5 \mathrm{ml}$. of inositol solution; after sterilization each flask was inoculated with $1 \mathrm{ml}$. of the standard yeast suspension and incubated with continual shaking for periods up to $68 \mathrm{hr}$. at $30^{\circ}$. The contents of the flasks were then centrifuged and suitable amounts of the supernatant liquids assayed for inositol. The residues in the centrifuge tubes were resuspended in $11 \mathrm{ml} .0 .9 \%$ saline with the addition of $1 \mathrm{ml} .40 \%$ formalin, and the amount of growth was estimated by comparison with standard yeast suspensions. From these experiments (see Fig. 1) it appeared that within wide limits all the inositol was removed from the medium. With very high concentrations of inositol, uptake continued until growth ceased (owing to exhaustion of some other nutrient) when uptake ceased also. As with $N$. gossypii the final amounts of growth, even where there was a marked deficiency of inositol in the medium, were very similar when sufficient time was allowed. It was subsequently found that even on media without inositol growth occurred slowly and eventually approached the maximum, whilst inositol in a bound form appeared in the organism. Thus it seems that $S$. carlsbergensis can, to a restricted degree, synthesize inositol though not sufficiently rapidly for normal healthy growth. As appears from Fig. 1 the difference to be observed at different inositol concentrations is in the rate rather than in the total amount of growth. For the concentrations used, the rate of growth was constant and practically the same during the first $18 \mathrm{hr}$. for all cultures except that in which there was no inositol. When the initial supply of inositol became exhausted the rate of growth fell off fairly sharply and became almost the same as that for the culture containing no inositol. This change of growth rate was observed in all cases providing that other nutrients were present in adequate amounts. Under conditions where growth could not take place no uptake of inositol from the medium was ever observed.

\section{The fate of inositol}

$N$. gossypii was grown on a medium containing adequate inositol, the mycelium collected, dried and extracted by refluxing with water or acid. After appropriate adjustments of $\mathrm{pH}$ and volume, the extracts were assayed for inositol. The results (Table 2) showed that under these conditions up to about $25 \%$ of the inositol removed from the medium could be recovered and that this amount at least is converted into a form from which inositol is liberated by acid hydrolysis.

S. carlsbergensis was grown on media containing $9 \mu \mathrm{g}$. inositol $/ \mathrm{ml}$. for periods up to $48 \mathrm{hr}$. After centrifuging, the supernatant liquid was assayed for inositol. The washed cells were dried at $98^{\circ}$ to constant weight and then extracted in various ways, in some cases with the addition of known amounts of inositol as a check on recovery. Assays were carried out on the extracts after adjusting to $\mathrm{pH} 4 \cdot 5$. Typical results are given in Table 3 . 


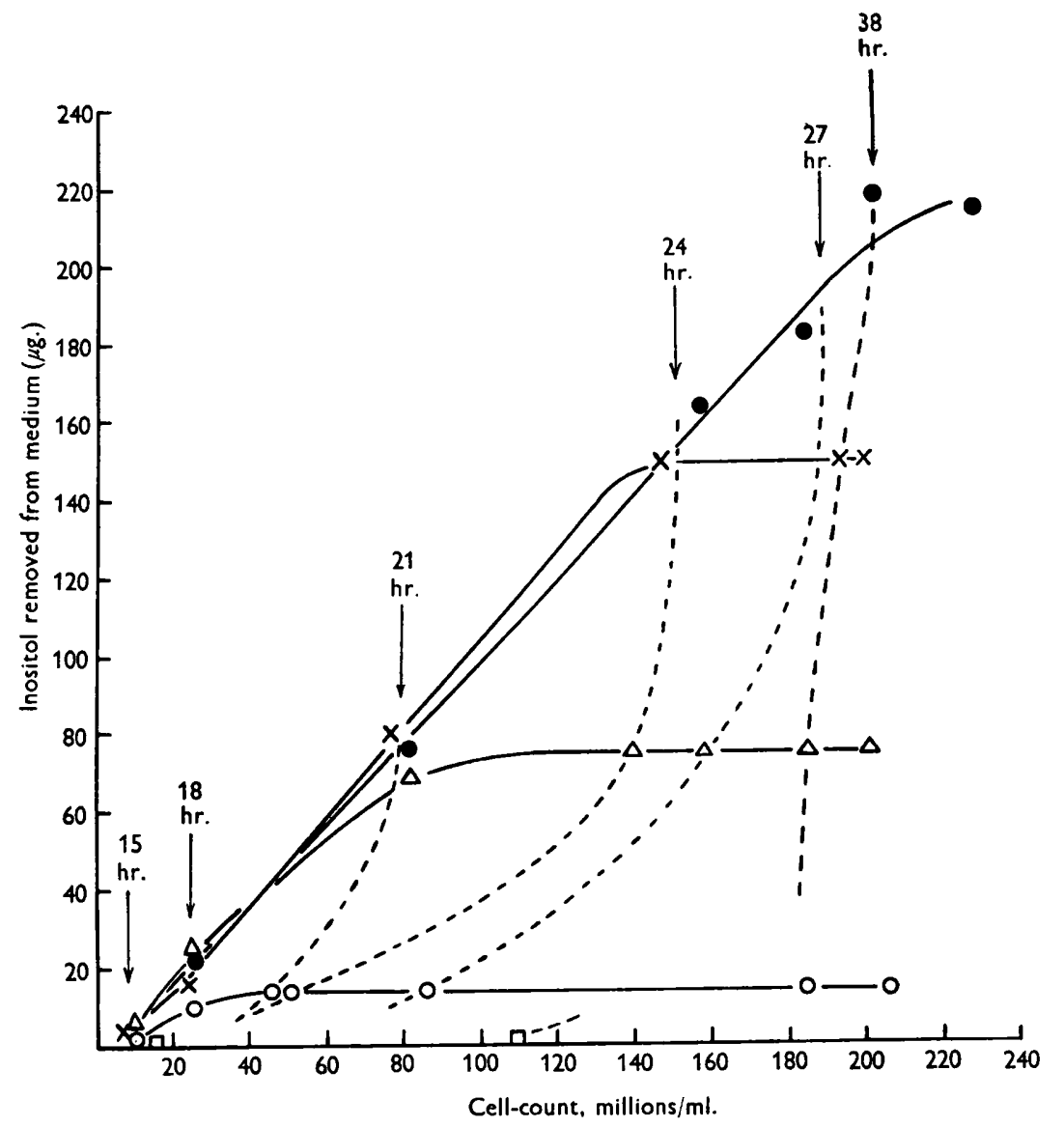

Fig. 1. Relation between uptake of inositol and growth of $\boldsymbol{S}$. carlsbergensis.

Inositol initially present in the medium:

$-300 \mu \mathrm{g}$; $-150 \mu \mathrm{g}$; $-\triangle \longrightarrow 75 \mu \mathrm{g} . ;-$

Table 2. Recovery of inositol from mycelium of $\mathbf{N}$. gossypii

Organism grown for 6 days at $30^{\circ}$ on $100 \mathrm{ml}$. medium containing (a) $1 \cdot 12 \mathrm{mg}$, (b) 0.42 mg. inositol.

Inositol removed from the medium (a) $0.98 \mathrm{mg} .,(b) 0.37 \mathrm{mg}$.

\section{Inositol recovered}

Method of extraction

$$
\text { of mycelium }
$$

(\% of uptake)

Refluxing with water,

12

$1 \mathrm{hr}$.

Refluxing with $5 \mathrm{~N}-\mathrm{HCl}$, $1 \mathrm{hr}$.

- $27 \cdot 5$


As noted above, slow growth of the yeast occurs even on media free from inositol. In one experiment for instance, the yeast was grown for $48 \mathrm{hr}$. on $200 \mathrm{ml}$. of an inositol-free medium. Aliquot portions (1/5) of the yeast produced were extracted with (a) boiling water for $20 \mathrm{hr}$., (b) $5 \mathrm{~N}-\mathrm{HCl}$ at $100^{\circ}$ for $20 \mathrm{hr}$. The extracts contained respectively $11 \mu \mathrm{g}$. and $180 \mu \mathrm{g}$. of inositol, showing that the yeast thus grown has a limited capacity to synthesize inositol which appeared largely in the form of a water-insoluble, acid-extractable compound.

Table 3. Recovery of inositol from $\mathbf{S}$. carlsbergensis

(i) Organism grown for $48 \mathrm{hr}$. at $30^{\circ}$ on $120 \mathrm{ml}$. of medium, containing $4.32 \mathrm{mg}$. inositol. Inositol removed from the medium, $3 \cdot 375 \mathrm{mg}$.

$\begin{array}{lc}\text { Method of extraction } & \begin{array}{c}\text { Inositol recovered } \\ \text { ( of uptake) }\end{array} \\ \text { Refluxing with water, } 6 \mathrm{hr} \text {. } & 7 \cdot 5 \\ \text { Autoclaving with water, } 15 \mathrm{lb} \text {./sq. in., } & 3 \cdot 8 \\ 1 \mathrm{hr} \text {. } & \\ \text { Refluxing with } 2 \mathrm{~N}-\mathrm{HCl}, 6 \mathrm{hr} \text {. } & 31 \\ \text { Autoclaving with } 2 \mathrm{~N}-\mathrm{HCl}, & 29 \\ 15 \mathrm{lb} / \mathrm{sq} \text {. in., } 1 \mathrm{hr} \text {. } & 21 \\ \text { Refluxing with } 2 \mathrm{~N}-\mathrm{NaOH}, 6 \mathrm{hr} . & 16 \\ \text { Autoclaving with } 2 \mathrm{~N}-\mathrm{NaOH}, & \\ 15 \text { lb./sq. in., } 1 \mathrm{hr} \text {. } & \end{array}$

(ii) Organism grown for $27 \mathrm{hr}$. at $30^{\circ}$ on $120 \mathrm{ml}$. medium, containing (a) $4.32 \mathrm{mg}$., (b) $1.08 \mathrm{mg}$. inositol. Inositol removed from medium, (a) $1.45 \mathrm{mg} .,(b) 0.49 \mathrm{mg}$.

Method of extraction
Refluxing with $5 \mathrm{~N}-\mathrm{HCl}, 20 \mathrm{hr}$.$\overbrace{\begin{array}{cc}\text { (a) } & \text { (b) } \\ \text { (\% of uptake) }\end{array}}^{\begin{array}{cc}\text { Inositol recovered } \\ \text { (a) }\end{array}}$

Inositol is widely distributed in nature in the form of phytin, which is hydrolysed with difficulty (Bartow \& Walker, 1938). Since it appeared possible that the bound form in which inositol is present in the organisms studied might in fact be phytin, this was estimated in the yeast by the method of Averill \& King (1926). In an experiment in which $8.7 \mathrm{mg}$. of inositol had been removed from the medium by the organism, $6 \cdot 6 \mathrm{mg}$. were estimated as present in the precipitated iron-phytin complex. This suggested that much of the bound inositol was indeed present as phytin, but as the method of estimation may lack specificity actual isolation of phytin is desirable.

\section{Abnormal growth of S. carlsbergensis lacking inositol}

In media deficient in inositol the cultures were abnormal in that the cells failed to divide completely, remaining in aggregates of up to 50 cells. Detergents had no effect upon these aggregates and it seemed possible that their formation was due to a failure in the last stages of cell division. Incubation with shaking at $30^{\circ}$ for $48 \mathrm{hr}$. in saline solution containing up to $100 \mu \mathrm{g}$. inositol $/ \mathrm{ml}$. was without observable effect upon these aggregates. 
Abnormalities in the appearance of certain micro-organisms lacking inositol have been noticed by other workers; thus Rao, Mistry \& Sreenivasaya (1946) found that toddy yeast became spongy, and Beadle (1944) found that the mycelium of a Neurospora tended to stick to the culture flask.

\section{The action of certain compounds related to inositol}

Since the observation of Woods (1940) that the bacteriostatic action of sulphanilamide is due to antagonism with the structurally related bacterial growth factor $p$-aminobenzoic acid, many cases of similar antagonism between growth substances and structural analogues have been recorded. The discovery by Peck $e$ al. (1946) that streptidine, which forms part of the streptomycin molecule, is a derivative of inositol suggested that the antibiotic action of streptomycin might arise in a similar manner. Streptidine, strepturea and streptamine were prepared from a sample of streptomycin by the method of Fried, Boyack \& Wintersteiner (1946) and the effect of these substances on the growth of $S$. carlsbergensis was tested to see whether any of them would antagonize or could replace inositol; $\gamma$-hexachlorocyclohexane was similarly tested. The yeast was grown for $18 \mathrm{hr}$. on the usual medium with the addition of inositol and the other compounds tested, in various combinations and in concentrations ranging from $0.00001 \mathrm{M}$ to $0.0015 \mathrm{M}$. $\gamma$-Hexachlorocyclohexane, being sparingly soluble, was added in strong ethanol solution, a test having shown that the presence of ethanol in similar concentration did not affect yeast growth. The results are expressed (Table 4) as the decrease of the reading on a Spekker turbidimeter due to the presence of the cells (i.e. the Spekker reading for the culture subtracted from the reading for the clear medium). This gives a measure in arbitrary units of the light absorption due to the presence of yeast cells, and varies with the number of cells present, although not directly proportional thereto. This experiment showed that, of the compounds tested, the only one possessing any activity was $\gamma$-hexachlorocyclohexane which caused a definite inhibition of growth. This inhibition, however, was not reversed by inositol even when the latter was present in a concentration 35 times as great as that needed for maximum growth.

Thus it seemed that the inhibition was not of the type in which the analogue reversibly competes with the growth factor in an enzyme system. Further evidence for this rests in the fact that the abnormal type of growth typical of inositol deficiency described above was not seen in cultures inhibited by $\gamma$-hexachlorocyclohexane. Streptidine, strepturea and streptamine had no growth-promoting activity.

\section{Inositol and the respiration of certain yeasts}

The effect of inositol on suitably respiring yeast cultures $(S$. carlsbergensis and a commercial lager yeast) was examined, but no significant differences in the rate of oxygen uptake could be detected. The experiments were carried out in the presence and absence of glucose and of phosphate; in some cases the yeast had been grown on a medium rich in inositol and in other cases on an 
Table 4. Effect of compounds related to inositol on growth of

S. carlsbergensis $\mathbf{4 2 2 8}$

Organism grown for $18 \mathrm{hr}$. at $30^{\circ}$.

\begin{tabular}{|c|c|c|c|c|}
\hline \multirow{2}{*}{$\begin{array}{c}\text { Compound tested } \\
\text { (M concentrations) }\end{array}$} & \multicolumn{4}{|c|}{ Concentration of inositol in medium } \\
\hline & \multicolumn{4}{|c|}{$\begin{array}{c}0 \\
\text { Decrease in Spekker reading }\end{array}$} \\
\hline Streptidine, & & & & \\
\hline 0.000016 & - & $1 \cdot 23$ & $1 \cdot 33$ & 1.33 \\
\hline 0.0015 & $0 \cdot 14$ & 1.29 & - & $1 \cdot 28$ \\
\hline Strepturea, & & & & \\
\hline 0.000016 & - & 1.27 & $1 \cdot 35$ & $1 \cdot 37$ \\
\hline 0.0015 & 0.17 & 1.29 & - & $1 \cdot 31$ \\
\hline Streptamine, & & & & \\
\hline 0.000016 & - & 1.23 & $1 \cdot 34$ & 1.27 \\
\hline 0.0015 & $0 \cdot 16$ & $1 \cdot 30$ & - & $1 \cdot 32$ \\
\hline -hexachlorocyclohexan & & & & \\
\hline 0.000016 & - & 0.14 & $0 \cdot 15$ & $0 \cdot 14$ \\
\hline (no addition) & $0 \cdot 16$ & 1.25 & $1 \cdot 32$ & 1.33 \\
\hline
\end{tabular}

Decrease in Spekker reading of 1.30 corresponds to approximately $25,000,000$ cells $/ \mathrm{ml}$. under the conditions of the experiment.

inositol-free medium. These negative results do not necessarily mean that inositol is not concerned in respiration, since the yeasts even when grown in an inositol-free medium contained inositol, and cells take up inositol only while growing.

Further experiments showed that the oxygen uptake of $S$. carlsbergensis was inhibited in the presence of $\gamma$-hexachlorocyclohexane; for example, in one experiment the oxygen uptake was $120 \mu \mathrm{l} . \mathrm{O}_{2} / 90 \mathrm{~min}$. in the presence of $\gamma$-hexachlorocyclohexane $(0.000016 \mathrm{M})$, compared with $160 \mu \mathrm{l}$. in a control experiment. The inhibition was not reversed by the addition of comparable amounts of inositol to the medium.

Extensive tests were also made with acetone-dried yeast preparations. With these, $\gamma$-hexachlorocyclohexane exerted no inhibitory effect nor did inositol influence the rate of oxygen uptake. It appeared, therefore, that the inhibition produced by $\gamma$-hexachlorocyclohexane with the intact cells was connected only indirectly with the respiratory enzymes. Finally, experiments using the Thunberg methylene blue technique failed to demonstrate the presence of an inositol dehydrogenase in S. carlsbergensis 4228 .

\section{DISCUSSION}

Although the importance of meso-inositol in nutrition has been recognized for many years, little progress has been made towards the elucidation of its mode of action. Evidence that it is concerned in some enzyme system would be provided if the theory of Slade (1945) concerning the toxicity of $\gamma$-hexachlorocyclohexane were proved, but observations by various workers on this subject are contradictory. (See Fromageot \& Confino, 1948; Chaix, Lacroix \& 
Fromageot, 1948; Thorp \& de Meillon, 1947). Only for pancreatic amylase(Lane $\&$ Williams, 1948) has any direct connexion been reported between inositol and a particular enzyme system. If an amylase is present in $S$. carlsbergensis it is likely to account only for a small proportion of the dry weight of the organism, whereas if the whole of the inositol recoverable from the yeast were present in the form of an amylase of a constitution similar to that studied by Lane \& Williams it would constitute almost the whole of the dry material of the organism. In general, purified enzymes have not been found to contain significant amounts of inositol; this has been noted by Williams, Schlenk \& Eppright (1944) for a number of enzymes, and in this laboratory for a purified potato phosphorylase prepared according to Bourne, Macey \& Peat (1945). This last preparation also was unaffected by $\gamma$-hexachlorocyclohexane.

Two facts seem to differentiate inositol from other members of the vitamin B group: (1) the relatively large amount required, i.e. 10 to 1000 times as much as for other B vitamins; (2) the chemically inert nature of the inositol molecule. These facts make it less likely that its principal function is that of an active component of an enzyme system. The attempts made in the present work to detect its influence on respiration, all of which yielded negative results, provide evidence supporting this view; Hopkins \& Pennington (1950) suggest that it is improbable that inositol forms part of a simple coenzyme in alcoholic fermentation.

Available evidence favours the view that inositol may be used in the formation of an actual building unit in the structure of the cell. Both $S$. carlsbergensis and $N$. gossypii were found to absorb considerable amounts of inositol during growth, in a quantity proportional to the amount of growth of the organism; when the external supply of inositol was exhausted there was an immediate slowing of growth rate comparable with that on an inositolfree medium. The abnormal type of growth noticed in deficiency of inositol is also understandable if the primary function of the substance is as a necessary structural unit rather than as an enzyme constituent. Up to $75 \%$ of the inositol absorbed during growth can be recovered by acid hydrolysis and seems to be present in a form resembling phytin. The amount of inositol recoverable both by water and acid extraction is greater when the yeast is grown on media relatively rich in inositol. Some organisms have been reported to oxidize inositol to the corresponding mono- or di-keto derivatives (Carter et al. 1948), but these substances have not been detected during this work.

The slow synthesis of inositol by $S$. carlsbergensis 4228 makes it important that the incubation period in assays with this organism should not be too long; since, however, there is practically no growth in the absence of inositol during the first $18 \mathrm{hr}$., the assay method using this period may be considered satisfactory.

The author wishes to thank Professor R. H. Hopkins for a culture of $S$. carlsbergensis; Mr H. J. Bunker for a supply of lager yeast; and Dr Melvyn Lumb for a generous gift of streptomycin. His thanks are due also to the Medical Research Council for the grant of a Studentship, and to Dr H. W. Buston for guidance throughout the work. 


\section{REFERENCES}

Atkin, L., Schultz, A. S., Williams, W. L. \& Frey, C. N. (1943). Yeast microbiological methods for determination of vitamins. Industr. Engng. Chem. Anal. Ed. 15, 141.

Averill, H. P. \& King, C. G. (1926). The phytin content of foodstuffs. J. Amer. chem. Soc. 48, 724.

Bartow, E. \& WALker, W. W. (1938). Inactive inositol and other products from starch factory steep water. Industr. Engng. Chem. 30, 300.

BeADle, G. W. (1944). Use in bioassays of mutant of Neurospora without inositol. J. biol. Chem. 156, 683.

Bourne, E. J., Macey, A. \& Peat, S. (1945). Enzymic synthesis and degradation of starch. II. J. chem. Soc. p. 877.

Buston, H. W. \& Pramanik, B. N. (1931). The accessory factor necessary for the growth of Nematospora gossypii. Biochem. J. 25, 1656.

Buston, H. W., Jacobs, S. E. \& Goldostern, A. (1946). Cause of physiological activity of 'gammexane'. Nature, Lond., 158, 22.

Carter, H. E., Belinskey, C., Clark, R. K., Flynn, E. H., Lytle, B., McCasLAND, G. E. \& Robbins, M. (1948). Oxidation of inositol by Acetobacter suboxydans. J. biol. Chem. 174, 415.

Chaix, P., Lacroix, L., \& Fromageot, C. (1948). La toxicité des hexachlorocyclohexanes vis-à-vis de Glaucoma piriformis (Tetrahymena gelleii). Biochim. Biophys. Acta, 2, 57.

EASTсотт, E. V. (1928). Wildier's bios. Isolation and identification of 'bios I'. J.phys. Chem. 32, 1094.

Fischer, E. H. \& Bernfeld, P. (1949). Amylolytic enzymes, XII. Helv. chim. Acta, 32, 1146.

Fried, J., Boyack, G. A. \& Wintersteiner, O. (1946). Streptomycin: chemical nature of streptidine. J. biol. Chem. 162, 391.

Fromageot, C. \& Confino, M. (1948). Hexachlorocyclohexanes et méso-inositol. Biochim. Biophys. Acta, 2, 142.

Hopkins, R. H. \& Pennington, R. J. (1947). The assay of the vitamin $B_{6}$ complex. Biochem. J. 41, 110.

Hopkins, R. H. \& Pennington, R. J. (1950). The effect of growth factor deficiencies upon fermentation of glucose by yeasts. J. gen. Microbiol. 4, 171.

Kirkwoop, S. \& Phillips, P. H. (1946). Anti-inositol effect of $\gamma$-hexachlorocyclohexane. J. biol. Chem. 163, 251.

LANE, R. L. \& Williams, R. J. (1948). Inositol, an active constituent of pancreatic (alpha) amylase. Arch. Biochem. 19, 329.

Peck, R. L., Hoffhine, C. E., Peel, E. W., Graber, R. P., Holly, F. W., Mozingo, R. \& Folkers, K. (1946). Streptomyces antibiotics. VII. J. Amer. chem. Soc. 68, 776.

Rao, T. N. R., Mistry, S. P. \& Sreenivasaya, M. (1946). Cyto-chemical studies of avitaminosis in toddy yeast. Curr. Sci. 15, 109.

Slade, R. (1945). Hurter Memorial Lecture. Chem. \& Industr. 314.

Thorp, J. M. \& De Meillon, B. (1947). Inhibition of the toxicity of 'Gammexane' for insects. Nature, Lond., 160, 264.

Williams, R. J., Schlenk, F. \& Eppright, M. A. (1944). Assay of purified proteins, enzymes, etc., for 'B vitamins'. J. Amer. chem. Soc. 66, 896.

WooDs, D. D. (1940). Relation of $p$-aminobenzoic acid to the mechanism of action of sulphanilamide. Biochem. J. 21, 74. 